\title{
Migration of intrauterine device into the pelvic cavity: exploration strategy and management in African environment
}

\section{Abdoul Aziz Diouf ${ }^{1 *}$, Moussa Diallo ${ }^{1}$, Omar Gassama $^{1}$, Mouhamadou Mansour Niang ${ }^{1}$,

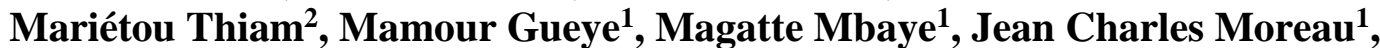 Bruno Van Herendael ${ }^{3}$, Alassane Diouf ${ }^{1}$}

\author{
${ }^{1}$ Université Cheikh Anta DIOP de Dakar \\ ${ }^{2}$ UFR Santé de Thiès \\ ${ }^{3}$ ZNA Stuivenberg Lange Beeldekensstraat, 267, 2060 Antwerpen
}

Received: 27 November 2016

Accepted: 20 December 2016

\section{*Correspondence:}

Dr. Abdoul Aziz Diouf,

E-mail: dizzefr@yahoo.fr

Copyright: () the author(s), publisher and licensee Medip Academy. This is an open-access article distributed under the terms of the Creative Commons Attribution Non-Commercial License, which permits unrestricted non-commercial use, distribution, and reproduction in any medium, provided the original work is properly cited.

\begin{abstract}
IUD migration is a rare complication. We report our experience in the treatment of five cases of uterine perforation and migration of IUDs. The average age of patients was 34.6 years, an average parity was 4. All patients felt an unusual pain during insertion of the IUD Tcu 380A. The location of the IUD was done through ultrasound and hysterography. Removal by laparoscopy was performed in all cases. The immediate impacts of the surgery were simple. Hysterography has its place in the location of the migrated IUD. Prevention is a good IUD insertion technique.
\end{abstract}

Keywords: Contraception, Complications, Intrauterine device, Laparoscopy

\section{INTRODUCTION}

IUD insertion is a simple medical procedure, but not without any risk. Migration after uterine perforation is one of the most uncommon complications regarding application of IUD. ${ }^{4}$ The management requires a rigorous approach based largely on medical imaging. MRI is currently the best way to locate the IUD; yet, in areas where this examination is not available, hysterography remains competitive as far as guiding the removal of IUDs safely is concerned. ${ }^{5}$ We hereby convey our experience in the management of uterine perforation and IUD migration in African environment.

\section{CASE REPORT}

The average age of patients was 34.6 years with a mean rate of 4 . Three patients out of five were in a period of late postpartum, more than 3 months before delivery. The
IUD was inserted by qualified staff in all cases (2 gynecologists and 3 midwives).
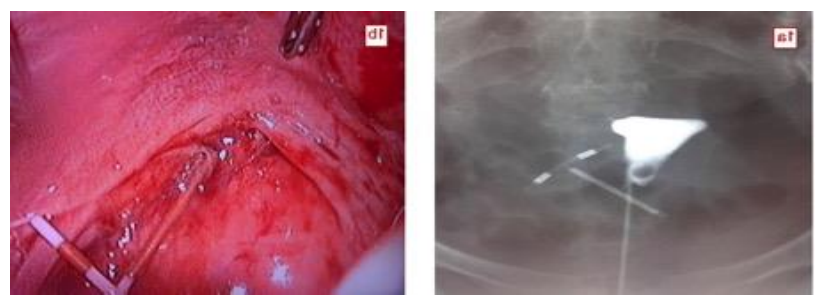

Figure 1: Uterine perforation by the copper IUD; (A) Hysterography (anterior/posterior) views showing the copper IUD outside the uterine cavity; (B)

Laparoscopy outlining the IUD puncturing the uterine isthmus and through the pouch of Douglas.

All patients felt an unusual pain at the time they were fitted with the 380-TCu A. This pelvic pain persisted in 
one patient only, while another showed amenorrhea revealing pregnancy of 8 weeks. The diagnosis was made by ultrasound with the IUD located outside the uterine cavity. In 4 cases, we performed hysteroscopy (front and profile views) to better visualize the IUD (Figure 1-3).
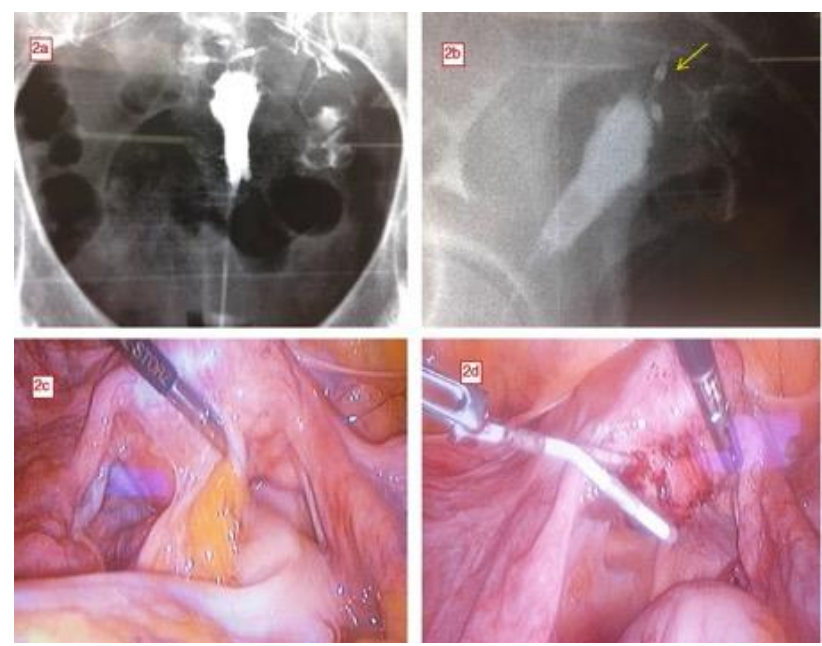

Figure 2: Perforation - migration of the copper IUD;

(2A, B); hysterography (anterior / posterior) and profile) views showing the two horizontal arms of the copper IUD outside the uterine cavity (arrow), specifically behind the uterus; (2C, D); Laparoscopy outlining the inflammatory adhesion of the sigmoid colon to the posterior wall of the uterus; adhesiolysis helped reach the IUD by inserting a vertical arm into the myometrium.

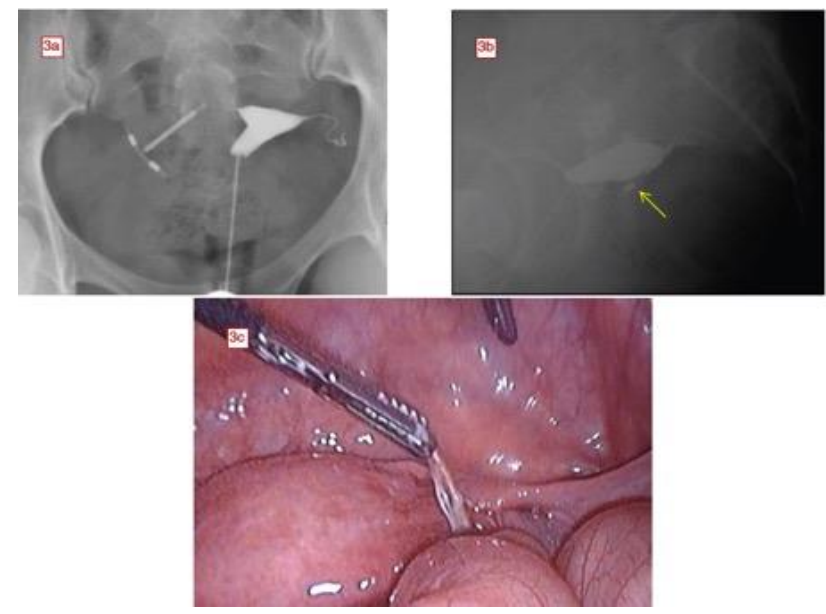

Figure 3: Perforation - migration of the copper IUD; (A, B); Hysterography (anterior/posterior and profile) views. The copper IUD is right and rear of the uterus; it is also tilted; (C); Laparoscopy facilitate removal of the IUD seating between the right fallopian tube and the posterior part of the ipsilateral broad ligament.

The injection of iodinated contrast agent was limited to the uterine cavity. The latter showed IUD outside the cavity, front or back of the uterus. The IUD removal was performed by laparoscopy; exploration showed a mild inflammatory change located around the IUD; the adnexa of uterus, small intestine nearby and mesenteries were involved. No hemostasis action was taken after removal of the IUD.

\section{DISCUSSION}

The IUD is a long-term, reversible, effective and safe method of contraception. Used by about 100 million women, it is now the most widespread reversible contraceptive method in the world. ${ }^{11}$ In Senegal, the IUD represents $4.1 \%$ of all modern contraceptive methods in use; nurses and midwives are legally entitled, after special training, to insert IUDs and perform check-ups. ${ }^{1}$ Uterine perforation after IUD insertion is a rare accident; its incidence varies in the literature, 0.1 to $3 / 1000 .^{3-7}$

The perforation can occur in two ways: immediately during insertion, following a technical failure of installation. It may be secondary to a partial myometrial perforation during installation. Intramyometrial migration begins with embedment of the IUD into the myometriumi; inflammatory phenomena and uterine contractions will allow the IUD to continue its migration. This inflammatory reaction leads to a significant accumulation of enzymes and of lytic/lysosomal substances causing endometrial destruction and secondary migration of the IUD under the action of uterine contractions. $^{7}$

Certain factors predispose to this migration: weakening of the myometrium by multiple pregnancies and cesarean scars; abnormal position, or size of the uterus; breastfeeding probably due to excessive uterine involution and endometrial atrophy as the consequence of lactation-induced hypoestrogenism. ${ }^{10}$ This was observed in four of the patients $(80 \%)$. Topographically, IUDs generally migrate into the peritoneal cavity (omentum, broad ligament, retropubic space), more rarely within an organ (ovary, proboscis, rectum, sigmoid colon, appendix, bladder), or exceptionally intravascular (stenosis of the iliac vein), sometimes in the subcutaneous fat. ${ }^{8}$

In case of ectopic IUD, pelvic examination is often not very successful. The symptoms can be reduced to the immediate pain caused by improper insertion of the device revealing iatrogenic perforation. ${ }^{4}$ Very often, uterine perforation by the IUD remains asymptomatic; the diagnosis is suspected in the absence of visualization of the retrieval strings at vagina level. ${ }^{8}$ Sometimes the puncturing is only detected at the stage of complications such as pelvic abscess, organ perforation like the bladder or digestive segment. ${ }^{2,6}$ Death as the result of digestive complication has been reported in the literature. ${ }^{8}$

The clinical diagnosis is not always easy, additional explorations are required to locate the intrauterine device. Pelvic ultrasound by transabdominal and transvaginal route is the first line examination in the event of doubt. ${ }^{5}$ 
This confirms the uterine migration by objectifying the uterine vacuity. This also contributes to highlighting a partial puncturing of the uterine wall by one of the IUD arms. Sonography can determine the exact position of ectopic IUD (intra-bladder, lateral or retro-uterine). ${ }^{8}$

If there is good visibility, IUDs will appear, according to the view, as a linear structure (sagittal plane) or strongly hyperechoic or two orthogonal arms (axial plane). ${ }^{8}$ However, the limits of ultrasound scanning often cannot objectify the IUD when the device is in an intraperitoneal position. Hysterography is the second-line examination when the IUD cannot be located intrauterinally by ultrasound. ${ }^{5}$ It will be performed under non-pregnancy state. In addition to having a wider field of vision than with ultrasound scanning, ingestion of iodinated contrast product followed by anterior/posterior and profile views gives a precise location of the IUD.

Yet, hysterography cannot help confirm the intramyometrial location or any organ of the pelvic cavity internally. This is why we always combine hysterography and ultrasound in the management strategy of this accident. CT scan and MRI have not been suggested in the case of our patients for reasons of cost and accessibility.

Table 1: General characteristics of patients with migration of intrauterine device (IUD) into the pelvic cavity.

\begin{tabular}{|c|c|c|c|c|c|}
\hline & Case 1 & Case 2 & Case 3 & Case 4 & Case 5 \\
\hline Age (years) & 28 & 35 & 38 & 37 & 39 \\
\hline Parity & 3 & 5 & 4 & 5 & 3 \\
\hline Type of IUD & $\mathrm{TCu} 380 \mathrm{~A}$ & $\mathrm{TCu} 380 \mathrm{~A}$ & $\mathrm{TCu} 380 \mathrm{~A}$ & $\mathrm{TCu} 380 \mathrm{~A}$ & $\mathrm{TCu} 380 \mathrm{~A}$ \\
\hline Antecedents & $\begin{array}{l}\text { Postpartum } \\
\text { (5 months) }\end{array}$ & Caesarean & $\begin{array}{l}\text { Postpartum (11 } \\
\text { months) }\end{array}$ & $\begin{array}{l}\text { Postpartum } \\
\text { (3 months) }\end{array}$ & any \\
\hline $\begin{array}{l}\text { Circumstance of } \\
\text { discovered }\end{array}$ & Pelvic pain & $\begin{array}{l}\text { Pregnancy } 14 \\
\text { weeks }\end{array}$ & Fil not felt & Any & Metrorrhagia \\
\hline Ultrasound & $\begin{array}{l}\text { IUD retro- } \\
\text { uterine position }\end{array}$ & IUD unseen & $\begin{array}{l}\text { IUD IN pouch } \\
\text { of Douglas }\end{array}$ & $\begin{array}{l}\text { IUD retro-uterine } \\
\text { position }\end{array}$ & IUD unseen \\
\hline Hystérography & + & - & + & + & + \\
\hline $\begin{array}{l}\text { Delay between } \\
\text { insertion of the IUD } \\
\text { and diagnosis }\end{array}$ & 1 week & 3 months & 15 days & 4 months & 5 months \\
\hline Therapeutic measures & Laparoscopy & Laparoscopy & Laparoscopy & Laparoscopy & Laparoscopy \\
\hline Location IUD & $\begin{array}{l}\text { Pouch of } \\
\text { Douglas }\end{array}$ & $\begin{array}{l}\text { Between ovarian } \\
\text { and pelvic left } \\
\text { wall }\end{array}$ & $\begin{array}{l}\text { Pouch of } \\
\text { Douglas }\end{array}$ & Retro-uterine & $\begin{array}{l}\text { Between the ovary } \\
\text { and broad ligament }\end{array}$ \\
\hline Adhesions & any & $\begin{array}{l}\text { Between left } \\
\text { ovary and pelvic } \\
\text { wall }\end{array}$ & $\begin{array}{l}\text { Between } \\
\text { sigmoid colon } \\
\text { and uterus }\end{array}$ & $\begin{array}{l}\text { Between sigmoid } \\
\text { colon and uterus }\end{array}$ & $\begin{array}{l}\text { Between the ovary } \\
\text { and broad ligament }\end{array}$ \\
\hline Complementary Care & Any & Any & Cleaning & Cleaning & Tubal sterilisation \\
\hline
\end{tabular}

The World Health Organization and the International Planned Parenthood Federation recommend removing the IUD once the diagnosis is made because intra-abdominal IUD can cause the formation of adhesions, chronic pelvic pain, bowel obstruction or even secondary migration into a hollow organ. ${ }^{8,9,11}$ The removal of the IUD by laparoscopy has the advantage of being less invasive and more convenient than laparotomy. This should be provided in case of laparoscopy failure or digestive or vesicouterine complications. $^{2}$

\section{CONCLUSION}

Uterine perforation by the copper IUD is not an exceptional occurrence in our regions. In the absence of CT scan or MRI, ultrasound-hysterography combination seems to be a good way of locating the IUD that must be part and parcel of the management strategy. Prevention requires compliance with the rules and techniques of IUD insertion.

\section{Funding: No funding sources \\ Conflict of interest: None declared \\ Ethical approval: Not required}

\section{REFERENCES}

1. WHO. Mechanism of action, safety and efficacy of intrauterine devices. Geneva: World Health Organization. 1987 p48-69.

2. Agence nationale de la statistique et de la démographie (ANSD) Dakar. Enquêtes démographiques et de santé à indicateurs multiples 
(EDS-MICS) 2010-2011: Rapport final. Calverton, 2010.

3. Andersson K, Ryde-Blomqvist E, Lindell K, Odlind V, Milsom I. Perforations with intrauterine devices. Report from a Swedish survey. Contraception. 1998;57(4):251-5.

4. Deshmukh S, Ghanouno P, Jeffrey RB. Early sonographic diagnosis of intrauterine device migration to the adnexa. J Clin Ultrasound. 2009;37(7):414-6.

5. Nohuz E et al. Un stérilet qui fait de plus en plus mal. où il ne suffit pas d'en voir les fils pour exclure une malposition! Gynecol Obstet Fertil. 2014;42(4):261-4.

6. Ech-Cherif El Kettani N, Dafiri R. Migration of intra uterine devises: role of imaging. Feuillets de Radiologie. 2007;47(3):159-66.

7. Bennis $\mathrm{H}$ et al. Migration transutérine des dispositifs intra-utérins. Rev Med Liège 2011;66(3):153-8.

8. Intra-uterine device's migration (DIU) with subsequent pelvic peritonitis in a 64 years old patient. Imagerie de la Femme. 2009;19(1):56-8.
9. Delotte J, Trastour C, Bafghi A, Iannelli A, Bongain A. Un motif de consultation surprenant: la perception de fils sortant par l'anus. À propos d'une complication rare de la pose de DIU. J Gynecol Obstet Biol Reprod. 2006;35(8):820-821.

10. Boyon G, Giraudet G, Guérin du Masgenêt B, Lucot JP, Goeusse P, Vinatier D. Diagnosis and management of uterine perforations after intrauterine device insertion: a report of 11 cases. Gynecol Obstet Fertil. 2013;41(5):314-21.

11. International Planned Parenthood (IPPF). International medical advasory panel meetings (IMAP). Statement on intrauterine devices (IUDs). IPPF Med Bull. 1987;21(6):3-5.

Cite this article as: Diouf AA, Diallo M, Gassama $\mathrm{O}$, Niang MM, Thiam MM, Gueye M, et al.

Migration of intrauterine device into the pelvic cavity: exploration strategy and management in African environment. Int J Reprod Contracept Obstet Gynecol 2017;6:757-60. 